\title{
Communication/Comunicação
}

\section{White piedra: molecular identification of Trichosporon inkin in members of the same family}

\author{
Piedra branca: identificação molecular do Trichosporon inkin em membros de mesma família
}

\section{Virgínia Bodelão Richini-Pereira ${ }^{1}$, Rosângela Maria Pires de Camargo ${ }^{2}$, Eduardo Bagagli $^{3}$ and Silvio AlencarMarques $^{2}$}

\begin{abstract}
Introduction: White piedra is a superficial mycosis caused by the genus Trichosporon and characterized by nodules on hair shaft. Methods: The authors report a family referred to as pediculosis. Mycological culture on Mycosel ${ }^{\circledR}$ plus molecular identification was performed to precisely identify the etiology. Results: A Trichosporon spp. infection was revealed. The molecular procedure identified the agent as Trichosporon inkin. Conclusions: White piedra and infection caused by T. inkin are rarely reported in Southern Brazil. The molecular tools are essentials on identifying the Trichosporon species.

Keywords: Trichosporon inkin. Piedra. PCR. Family case.
\end{abstract}

\section{RESUMO}

Introdução: Piedra branca é micose superficial causada por fungos do gênero Trichosporon e caracterizado por nódulos firmemente aderidos à haste do pêlo. Métodos: Os autores relatam casos familiares encaminhados como pediculose. Foram utilizados cultura em ágar Mycosel e e identificação molecular. Resultados: Exame micológico revelou a infecção por Trichosporon spp. A identificação molecular demonstrou se tratar do Trichosporon inkin. Conclusões: Piedra branca e infecção pelo T. inkin são raramente relatados na região sudeste do Brasil. A identificação molecular é essencial para correta determinação de espécies no gênero Trichosporon.

Palavras-chaves: Trichosporon inkin. Piedra. PCR. Casos familiares.

Superficial mycoses are fungal infections of the skin, hair, and nail that invade only the stratum corneum and the superficial layers of the skin. Piedra is an asymptomatic superficial fungal infection of the hair shaft. It was classified by Horta in 1911 into two types: black piedra, which is caused by Piedraia hortae, and white piedra, which is caused by genus Trichosporon. The clinical characteristic of white piedra is in the form of concretions or soft, whitish nodules on hair shaft ${ }^{1,2}$. Most cases occur in tropical and subtropical regions. Humidity, hyperhidrosis, and poor personal hygiene are important predisposing factors ${ }^{2}$. The Trichosporon genus has undergone extensive taxonomic reevaluation ${ }^{3,4}$. Traditional taxonomy based on morphological, ecologic, and physiological aspects is used to group the genus Trichosporon, which usually generates inconsistent results. The reclassification based on new taxonomic concepts, including

1. Laboratório de Biologia Molecular Aplicada às Zoonoses, Departamento de Higiene Veterinária e Saúde Pública, Universidade Estadual Paulista, Botucatu, SP. 2. Departamento de Dermatologia e Radioterapia, Faculdade de Medicina, Universidade Estadual Paulista, Botucatu, SP. 3. Departamento de Microbiologia e Imunologia, Instituto de Biociências, Universidade Estadual Paulista, Botucatu, SP. Address to: Dr. Silvio Alencar Marques. Dept ${ }^{\circ}$. Dermatologia Radioterapia/FM/ UNESP. Distrito de Rubião Júnior s/n, 18619-970 Botucatu, SP, Brasil.

Phone: 55 14 3811-6015; Fax: 55 14 3882-4922

e-mail: smarques@fmb.unesp.br

Received in 01/10/2010

Accepted in 21/02/2011 phylogenetic studies, was supported by the analysis of $26 \mathrm{~S}$ ribosomal DNA. Six species are relevant in medical mycology: Trichosporon asahii, Trichosporon asteroides, Trichosporon cutaneum, Trichosporon inkin, Trichosporon mucoides, and Trichosporon ovoides ${ }^{4}$. The etiologic agents of trichosporonosis differ according to infection: T. asahii and T. mucoides are involved in systemic infections, T. asteroids and T. cutaneum are associated with superficial infection, and T. ovoides and T. inkin are usually involved in white piedra of the scalp and the genital area, respectively ${ }^{5}$.

The study included three related members: a 36-year-old woman, the mother; the 3-year-old son; and the 6-year-old daughter. The index case was the 6-year-old child referred from a small community as a case of pediculoses resistant to treatment. Clinical examination showed multiple whitish nodules firmly attached to the hair shaft. Mycological examination and culture confirmed the clinical suspicion of white piedra. It was the first of such diagnosis in 36 years of existence of the local department of Dermatology in São Paulo State, Brazil. The patients were cured within a month after being treated systemically with itraconazol and topically with ketoconazole shampoo.

The mycological observations included direct microscopic examination of hair samples and culture in Agar Mycosel ${ }^{\circledR}$. They were incubated at room temperature $\left(28-30^{\circ} \mathrm{C}\right)$ up to 4 weeks.

The DNA extraction from Trichosporon spp. was performed according to the methods proposed by Van Burik ${ }^{6}$ using the Kit Illustra Tissue \& Cells genomic Prep Mini Spin ${ }^{\circledast}$ (GE Healthcare, USA). The amplification was carried out by PCR reactions, using, as primers, ITS4 (5'-TCCTCCGCTTATTGATATGC-3') and ITS5 (5'-GGAAGTAAAAGTCGTAACAACG-3') that amplified 634 bp as described by White et al. ${ }^{7}$ The process was performed in $25 \mu \mathrm{L}$ containing 1X PCR buffer (10mM Tris $\mathrm{HCl} \mathrm{pH} 8.0,50 \mathrm{mM} \mathrm{KCl})$, $1.5 \mathrm{mM} \mathrm{MgCl} 2,200 \mu \mathrm{M} \mathrm{dNTP}, 10 \rho \mathrm{mol}$ of each primer, $10 \mathrm{ng}$ of purified DNA, and 0.2 U. $\mu \mathrm{L}-1$ of Platinum Taq DNA polimerase system (Invitrogen, Brazil). Thermal cycling conditions were $94^{\circ} \mathrm{C}$ for $5 \mathrm{~min}$, followed by 25 cycles at $94^{\circ} \mathrm{C}$ for $1 \mathrm{~min}$, at $60^{\circ} \mathrm{C}$ for $2 \mathrm{~min}$, and $72^{\circ} \mathrm{C}$ for $2 \mathrm{~min}$ and a final extension at $72^{\circ} \mathrm{C}$ for $7 \mathrm{~min}$. PCR products were identified by agarose gel electrophoresis. Amplicons were purified by employing the commercial GFX ${ }^{\text {тx }}$ PCR DNA and Gel Band Purification kit (GE Healthcare). Using the sequencer MegaBace $^{\mathrm{TM}} 1,000$ (GE Healthcare), reactions were carried out in both strands according to DYEnamic ${ }^{\mathrm{TM}}$ ET Dye Terminator Cycle Sequencing Kit (GE Healthcare). Sequences were analyzed through Chromas 2.3 and MEGA 4 software and compared with the NCBI database (http://www.ncbi.nlm.nih.gov/BLAST).

Microscopic examination of hair samples presented ectothrix mass of fungal cells showing only arthrospores and blastospores 
typical of white piedra (Figure 1). The culture in Agar Mycosel $₫$ for 2 weeks produced a wrinkled white-to-cream yeast-like colony (Figure 2). Hyaline hyphae with many arthrospores and few blastospores were observed on microscope (Figure 3).

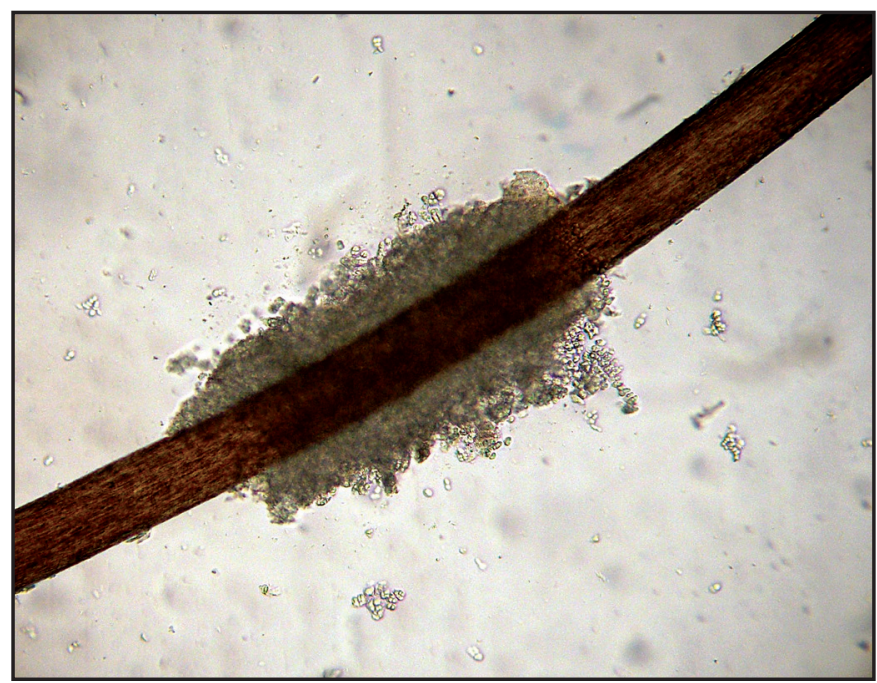

FIGURE 1 - Ectothrix mass of fungal cells attached to the hair shaft.

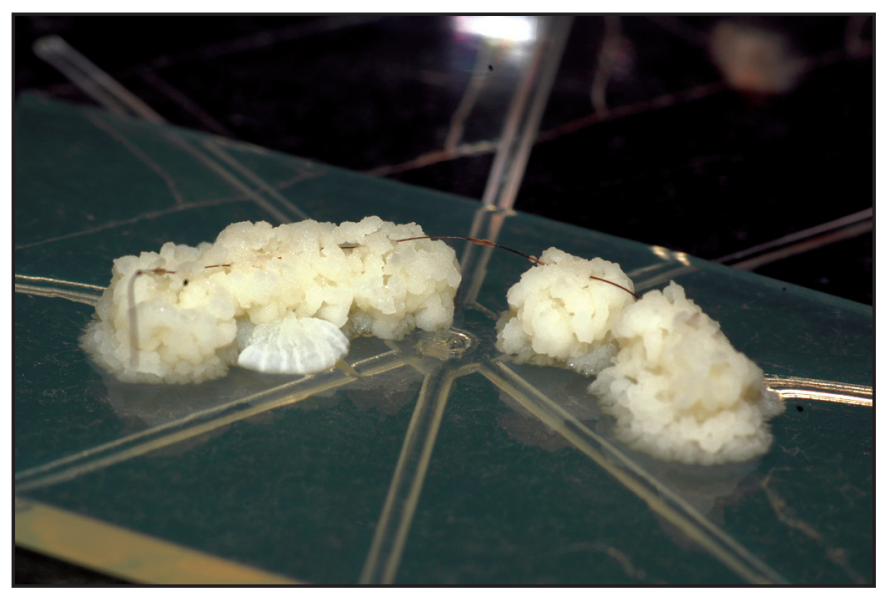

FIGURE 2 - Culture in Agar Mycosel ${ }^{\circledR}$ produced a wrinkled white-to-cream yeast-like colony.

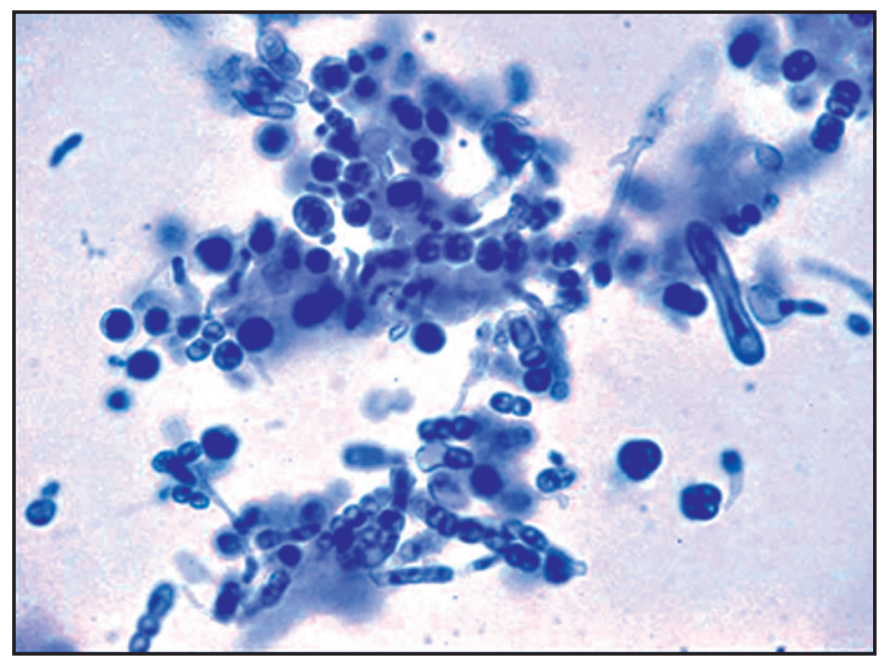

FIGURE 3 - On microscope, hyaline hyphae with arthrospores and blastospores were observed.
The molecular identities of these amplicons were confirmed by sequencing, which showed $98 \%$ similarity with Trichosporon inkin DNA sequence deposited at Gen Bank (gb|AF 444420.1, strain CBS 5585).

White piedra is an uncommon diagnosis in the southeast of Brazil, although some outbreak of scalp white piedra has been reported ${ }^{8,9}$. Out of the 20 reported cases, $90 \%$ were observed in children under 9 years old, and all were in female patients ${ }^{8,9}$. Most were correlated with informed behavior of routinely using emollient creams on hair. There were no familial cases in those reports. The scalp lesions of white piedra are usually asymptomatic and can be misdiagnosed as pediculoses.

The diagnosis of $T$. inkin was confirmed by means of morphological and molecular studies. Phenotypic methods for Trichosporon species identification are based on the characterization of micromorphological aspects of the colonies. It is a useful tool for triage, but because it is unable to differentiate all Trichosporon species, molecular techniques are considered the most reliable methods for species identification $^{10-12}$.

The identification of this microorganism using ribosomal genes represents consistent evolutionary markers, including alternating conserved and variable regions, which may be useful for species identification and phylogenetic studies ${ }^{13,14}$. Universal primers, ITS4 and ITS5, are sufficiently discriminatory for the identification of a considerable number of species of the genus Trichosporon ${ }^{15}$. It is worth mentioning that the genus Trichosporon is not only the agent of white piedra but also the second most commonly reported cause of disseminated yeast infection in humans, mainly in immunosuppressed patients ${ }^{4}$.

\section{CONFLICT OF INTEREST}

The authors declare that there is no conflict of interest.

\section{REFERENCES}

1. Schwartz RA. Superficial fungal infections. Lancet 2004; 364:1173-1182.

2. Bonifaz A, Gómez-Daza, F, Paredes V, Ponce RM. Tinea versicolor, tinea nigra, white piedra, and black piedra. Clin Dermatol 2010, 28:140-145.

3. Guého E, Smith MT, Hoog GS, Billon-Grand G, Christen R, Batenburg van der Vegte WH. Contributions to a revision of the genus Trichosporon. Antonie Van Leeuwenhoek 1992; 61:289-316.

4. Chagas-Neto TC, Chaves GM, Colombo AL. Update on the Genus Trichosporon. Mycopathologia 2008; 166:121-132

5. Gueho E, Improvisi L, Hoog GS, Dupont B. Trichosporon on humans: A practical account. Mycoses 1994; 37:3-10.

6. Van BurikJAH, Schreckise RW, White TC, Bowden RA, Myerson D. Comparison of six extration techniques for isolation of DNA from filamentous fungi. Med Mycol 1998; 36:299-303.

7. White TJ, Bruns T, Lee S, Taylor J. Amplification and direct sequencing of fungal ribosomal RNA genes for phylogenetics. In: Innis MA, Gelfand DH, Sninsky JJ, White TJ, editors. PCR Protocols: A Guide to Methods and Applications. San Diego: Academic Press; 1990. p. 315-322.

8. Diniz LM, Souza Filho JB. Estudo de 15 casos de piedra branca observados na Grande Vitória (Espírito Santo-Brasil) durante cinco anos. An Bras Dermatol 2005 ; 80:49-52.

9. Roselino AM, Seixas AB, Thomazini JA, Maffei CML. An outbreak of scalp white piedra in a Brazilian day care. Rev Inst Med Trop São Paulo 2008; 50:307-309.

10. Sugita T, Nishikawa A, Shinoda T, Kume H. Taxonomic position of deep-seated, mucosa-associated, and superficial isolates of Trichosporon cutaneum from trichosporonosis patients. J Clin Microbiol 1995; 33:1368-1370. 
11. Hoogs GS, Guarro J, Gene J, Figueras MJ. Atlas of clinical fungi. $2^{\text {th }}$ ed. Rio de Janeiro: Guanabara; 2000.

12. Pincus DH, Orenga S, Chatellier S. Yeast identification-past, present, and future methods. Med Mycol 2007; 45:97-121.

13. Ciardo DE, Schar G, Bottger EC, Altwegg M, Bosshard PP. Internal transcribed spacer sequencing versus biochemical profiling for identification of medically important yeasts. J Clin Microbiol 2006; 44:77-84.
14. Sugita T, Makimura K, Nishikawa A, Uchida K, Yamaguchi H, Shinoda T. Partial sequences of large subunitribosomal DNA of a new yeast species, Trichosporon domesticum and related species. Microbiol Immunol 1997; 41:571-573.

15. Sugita T, Nakajima M, Ikeda R, Matsushima T, Shinoda T. Sequence analysis of the ribosomal DNA intergenic spacer 1 regions of Trichosporon species. J Clin Microbiol 2002; 40:1826-1830. 